\title{
Soil Macrofauna and Edaphic Properties in Coffee Production Systems in Southern Colombia
}

\author{
Leonardo Rodríguez Suárez ${ }^{1}$ (D), Sandra Patricia Cuarán Pinto², \\ Juan Carlos Suárez Salazar³ ${ }^{3}$ (D)
}

${ }^{1}$ Programa de maestría en sistemas sostenibles de producción, Universidad de la Amazonia, Florencia/Caquetá, Colombia ${ }^{2}$ Programa de maestría en agroforestería, Universidad de la Amazonia, Florencia/Caquetá, Colombia ${ }^{3}$ Programa de ingeniería agroecológica, Universidad de la Amazonia, Florencia/Caquetá, Colombia

\begin{abstract}
The objective of this study was to evaluate the occurrence of the soil macrofauna in coffee production systems, as well as their relationship with edaphic properties. Therefore, two coffee production systems were selected: coffee plantations at full-sun with conventional management (Intensive) and shaded coffee plantations with organic management (Traditional). In each crop system, three soil samples were collected randomly, in the form of blocks $(25 \times 25 \mathrm{~cm})$, to a soil depth of $10 \mathrm{~cm}$. In total, 17,109 individuals were recorded in this study being the Oligochaeta group the most representative, regardless of the coffee production system. The average density of soil macrofauna was higher in traditional coffee plantations $(\mathrm{p}<0.05)$ due to the higher density of Oligochaeta, Diplopoda and Blattodea. The traditional coffee plantations provided a better soil chemical fertility reflected in the principal component analysis. Furthermore, these chemical attributes probably could affect the occurrence of the soil macrofauna groups.
\end{abstract}

Keywords: co-inertia analysis, organic management, shade trees, edaphic fauna. 


\section{INTRODUCTION}

In Colombia coffee is grown at full-sun, but it is common to observe coffee plantations associated with different types of shade trees (Arcila et al., 2007). Indeed, from 920,200 hectares cultivated with coffee, about $50 \%$ is grown under a canopy of shade trees (Farfán, 2014). Farmers' preference for no-shade system in the coffee plantations is thought to be mainly driven by the economic advantages and short-term profit (Guimarães et al., 2016), although no-shade coffee plantations generally require higher fertilizers, pesticides and labor (Sauvadet et al., 2019). This management practices often have a negative effect on soil quality, with a higher tendency to soil compaction, loss of mineral nutrients, and reduction of soil biota (Vasconcellos et al., 2013).

In recent years, the environmental challenges encountered in no-shade coffee plantations is prompting a reversal to the use of shade trees and a reduction of agrochemical use (Tscharntke et al., 2011). The use of tree species within the coffee plantation reduces the entry of sun-light, increases soil organic matter, soil nutrients and soil moisture, which allows the conservation of soil quality and soil biota (Guimarães et al., 2015). Furthermore, the organic coffee production system has emerged as an alternative to increase economic profitability, environmental conservation and human health (Lammel et al., 2015). This set of practices increases the sustainability of coffee plantations and positively influences in the reestablishment of soil invertebrate community (Guimarães et al., 2017).

Soil macrofauna constitutes an important component of soil biota given the significant impact of their activities in ecosystem functions (Kamau et al., 2017), besides being part of different trophic levels, presents interactions with the edaphic properties (Lavelle et al., 2006). There are physical and chemical soil properties that interact with soil macrofauna groups by influencing their metabolism, while at the same time responding to the behavior of soil macrofauna (Santos et al., 2018; Oliveira et al., 2018). The most cited physical properties are soil texture, soil density and porosity, which are associated with soil structure (Rousseau et al., 2012), while the chemical properties are associated to organic matter content, soil fertility and nutrient availability (Lima et al., 2010). As reported by Santos et al. (2018), chemical attributes may have a great impact on soil macrofauna, and some chemical properties clearly correlated much better with soil macrofauna than with other soil attributes under coffee plantations.

In this context, the objective of this study was to evaluate the occurrence of the soil macrofauna in two systems of coffee production and its relationship with edaphic properties. For this, the following hypotheses were formulated: i) shaded coffee production systems benefit the density and diversity of soil macrofauna due to tree cover that modifies the conditions under its canopy; and ii) the macrofauna are correlated with edaphic properties due to their role in the regulation of key soil functions, such as decomposition of soil organic matter, nutrient cycling and maintenance of soil structure.

\section{MATERIAL AND METHODS}

The study was conducted in 2016 in the Pitalito-Huila municipality $\left(1^{\circ} 51^{\prime} 14^{\prime \prime} \mathrm{N}, 76^{\circ} 03^{\prime} 05^{\prime \prime} \mathrm{O}\right)$. A total of 30 coffee (Coffea arabica L.) lots were studied. Two coffee production systems were evaluated as follows:

Intensive coffee plantations: Coffee production system presents densities greater than 7,000 trees $\mathrm{ha}^{-1}$ of the variety Castilla at full-sun exposure. The crop system receives at least three applications of urea (600 $\mathrm{kg} \mathrm{ha}^{-1}$ per year), diammonium phosphate (DAP; $110 \mathrm{~kg} \mathrm{ha}^{-1}$ per year) and potassium chloride $\left(\mathrm{KCl} ; 315 \mathrm{~kg} \mathrm{ha}^{-1}\right.$ per year) per year, and the intensive use of fertilizers and pesticides.

Traditional coffee plantations: Coffee production system presents densities smaller than 5,500 trees $\mathrm{ha}^{-1}$ of the variety Castilla and is traditionally grown under a canopy of shade trees (Inga sp. and Erythrina sp.). In parallel, the system is linked to an organic certification program, for which it refrains of the agrochemical use. The crop system receives regularly applications of compost and coffee husks.

To collect the soil macrofauna, the ISO 23611-5 standard was followed. Three monoliths were made per lot $(25 \times 25 \mathrm{~cm}$ blocks up to $10 \mathrm{~cm}$ of soil depth). The soil was manually checked in situ. The soil macrofauna was preserved in $70 \%$ alcohol and separated into large taxonomic units (class or order). At the sampling points of the soil macrofauna, soil samples were also taken for the characterization of edaphic properties such as 
$\mathrm{pH}$ (potentiometer method in water), organic carbon (Walkley-Black method), total nitrogen (Kjeldahl), phosphorus (modified Bray II method), total bases $(\mathrm{K}, \mathrm{Ca}, \mathrm{Mg}, \mathrm{Na}$ ) (extraction with $1 \mathrm{~N}$ and neutral ammonium acetate), exchangeable acidity (volumetry), cation exchange capacity (extraction with $1 \mathrm{~N}$ and neutral ammonium acetate), texture (Bouyoucos method) and bulk density (cylinder method of known volume). All techniques for the physical and chemical properties were based on the methods of soil analysis described by Zamudio et al. (2006).

We estimated the abundance of soil macrofauna by transforming the number of individuals found in each sample into the number of individuals per square meter (individuals. $\mathrm{m}^{-2}$ ). The data was analyzed with analysis of variance and Fisher's LSD test $(\mathrm{p}<0.05)$ if it fitted a normal distribution; otherwise, a nonparametric Kruskal-Wallis analysis $(\mathrm{p}<0.05)$ in the InfoStat (Di Rienzo et al., 2018) software was performed.

In order to analyze the overall effect of coffee production systems on the soil macrofauna and edaphic properties, principal component analysis (PCA) were performed. Prior to PCA, the soil macrofauna relative abundance were log transformed to decreasing the effect of dominant groups. To test for a significant effect of coffee plantations on soil macrofauna and edaphic properties, permutation Monte-Carlo tests were performed. Finally, the association between soil macrofauna relative abundance and edaphic properties was analyzed using co-inertia analysis (Dray et al., 2003) and Pearson's correlation coefficients were calculated. To display the correlations, the heatmap were constructed. All the multivariate statistical analyses were performed using R v.3.4.4 (R Core Team, 2018), and the packages "ade4", "ggplot2", "factoextra" and "corrplot".

\section{RESULTS AND DISCUSSION}

In total, 17,109 individuals were obtained in this study, being Oligochaeta the most representative group in both coffee production systems (Table 1). The average density of soil macrofauna was significantly $(\mathrm{p}<0.05)$ higher in traditional coffee plantations than in the intensive (Table 1). There were found 15 large taxonomic units, presenting significant differences $(\mathrm{p}<0.05)$ for Blattodea, Diplopoda and Oligochaeta (Table 1).
According to Pompeo et al. (2016), the primary decomposers (Blattodea) are related to sites with greater diversity and quantity of deposited plant material, which explains the relationship of this group with traditional coffee plantations due to the diverse contribution of leaf litter by shadow trees. Likewise, this trend was found for Diplopoda, for which they have been described as important due to their ecological function in terms of the initial fragmentation of all types of soil organic waste (Teixeira et al., 2014).

A lower density of Oligochaeta group in systems with intensive management can be explained by the use of herbicides (García-Pérez et al., 2014) and pesticides (Bartz et al., 2009). In fact, there would be expected a greater occurrence of Oligochaeta in more sustainable management systems, such as the organic management (Lammel et al., 2015). Particularly Aquino et al. (2008), when evaluating soil worms in coffee systems, also found lower density of earthworms in coffee crops at full-sun with conventional management compared to shaded coffee plantations and organic management.

According to the principal component analysis (p-value: 0.28 Monte Carlo test, Figure 1), in general

Table 1. Density (individuals. $\mathrm{m}^{-2} \pm$ Standard error) of soil macrofauna groups of the coffee production systems in southern Colombia.

\begin{tabular}{lrrrr} 
& \multicolumn{1}{c}{ Intensive } & & Traditional \\
\cline { 2 - 2 } \cline { 5 - 6 } & $\begin{array}{c}\text { coffee } \\
\text { plantations }\end{array}$ & & $\begin{array}{c}\text { coffee } \\
\text { plantations }\end{array}$ \\
Araneae & $6.40 \pm 1.64 \mathrm{a}$ & & $3.00 \pm 1.23 \mathrm{a}$ \\
\hline Blattodea & $0.36 \pm 0.36 \mathrm{~b}$ & $2.67 \pm 1.10 \mathrm{a}$ \\
\hline Chilopoda & $12.44 \pm 2.92 \mathrm{a}$ & $10.00 \pm 2.11 \mathrm{a}$ \\
\hline Collembola & $1.78 \pm 1.16 \mathrm{a}$ & $4.67 \pm 1.34 \mathrm{a}$ \\
Coleoptera & $41.24 \pm 8.32 \mathrm{a}$ & $43.33 \pm 6.70 \mathrm{a}$ \\
\hline Dermaptera & $8.53 \pm 3.51 \mathrm{a}$ & $5.67 \pm 1.61 \mathrm{a}$ \\
\hline Diplopoda & $6.04 \pm 2.11 \mathrm{~b}$ & $17.67 \pm 4.13 \mathrm{a}$ \\
\hline Diptera larvae & $2.13 \pm 0.82 \mathrm{a}$ & $4.00 \pm 1.21 \mathrm{a}$ \\
\hline Hemiptera & $2.84 \pm 1.37 \mathrm{a}$ & $5.33 \pm 2.25 \mathrm{a}$ \\
\hline Hymenoptera & $28.44 \pm 5.31 \mathrm{a}$ & $27.00 \pm 5.11 \mathrm{a}$ \\
\hline Isopoda & $5.33 \pm 1.69 \mathrm{a}$ & $6.33 \pm 2.77 \mathrm{a}$ \\
\hline Isoptera & $18.84 \pm 7.41 \mathrm{a}$ & $14.33 \pm 7.77 \mathrm{a}$ \\
\hline Lepidoptera larvae & $0.71 \pm 0.50 \mathrm{a}$ & $2.33 \pm 1.17 \mathrm{a}$ \\
\hline Oligochaeta & $341.70 \pm 37.1 \mathrm{~b}$ & $468.70 \pm 46.60 \mathrm{a}$ \\
\hline Symphyla & $4.98 \pm 1.59 \mathrm{a}$ & $2.67 \pm 1.10 \mathrm{a}$ \\
\hline Density total & $481.80 \pm 36.7 \mathrm{~b}$ & $617.7 \pm 48.30 \mathrm{a}$ \\
\hline Richness & $4.84 \pm 0.26 \mathrm{a}$ & $5.00 \pm 0.27 \mathrm{a}$ \\
\hline
\end{tabular}

Mean: 15 replicate \pm Standard error. Averages followed by equal letters in the row do not differ from each other at 5\% probability. 


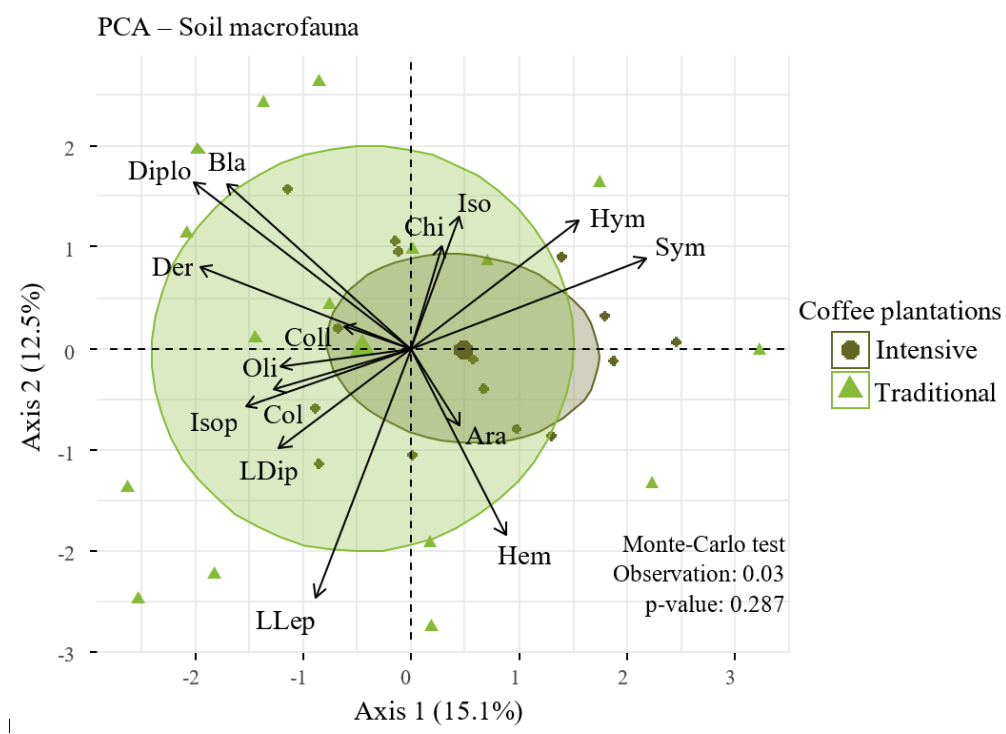

Figure 1. Projection in the F1/F2 factorial plane from a principal component analysis of the soil macrofauna and from sampling points grouped according to the coffee production system. Ara: Araneae; Bla: Blattodea; Chi: Chilopoda; Coll: Collembola; Col: Coleoptera; Der: Dermaptera; Diplo: Diplopoda; Oli: Oligochaeta; Hem: Hemiptera; Hym: Hymenoptera; Iso: Isopoda; Isop: Isoptera; LDip: Diptera larvae; LLep: Lepidoptera larvae; Sym: Symphyla.

the effect of coffee production systems on the soil macrofauna was not significant. The axis 1 indicated that Symphyla and Hymenoptera abundance were associated with intensive coffee plantations, while Diplopoda, Dermaptera, Blattodea and Isoptera abundance were associated with traditional coffee plantations (Figure 1). On the other hand, the axis 2 showed that Lepidoptera and Hemiptera abundance was related with traditional coffee plantations (Figure 1). However, the separation of the centroids that represent the coffee production systems in the factorial plane of the PCA was not evident (Figure 1).

In total, 14 edaphic properties were evaluated, from which eight presented significant differences $(\mathrm{p}<0.05)$ between coffee production systems (Table 2$)$. The traditional coffee plantations were characterized by a clay-loam texture, while the intensive coffee plantations showed a loam texture. In this sense, there were significant differences in clay content (Table 2). Soil acidity $(\mathrm{pH})$ in coffee production systems corresponded to acid soils with significantly higher values in traditional coffee plantations (Table 2). These results coincide with Santos et al. (2018), who report an increase of soil $\mathrm{pH}$ up to 6.0 in coffee plantations under organic management.

The soil organic carbon presented relatively high percentages, although it was higher in traditional coffee plantations (Table 2). This is similar to what
Table 2. Edaphic properties evaluated in coffee production systems in southern Colombia.

\begin{tabular}{|c|c|c|}
\hline & Intensive & Traditional \\
\hline & $\begin{array}{c}\text { coffee } \\
\text { plantations }\end{array}$ & $\begin{array}{c}\text { coffee } \\
\text { plantations }\end{array}$ \\
\hline $\mathrm{pH}$ & $4.89 \pm 0.14 b$ & $5.71 \pm 0.15 \mathrm{a}$ \\
\hline OC (\%) & $2.28 \pm 0.20 \mathrm{~b}$ & $2.82 \pm 0.19 a$ \\
\hline $\mathrm{N}(\%)$ & $1.06 \pm 0.02 \mathrm{~b}$ & $1.15 \pm 0.03 \mathrm{a}$ \\
\hline $\mathrm{P}(\mathrm{ppm})$ & $1.53 \pm 0.02 a$ & $1.56 \pm 0.02 \mathrm{a}$ \\
\hline $\mathrm{K}\left(\right.$ meq $\left.100 \mathrm{~g}^{-1}\right)$ & $0.56 \pm 0.05 b$ & $0.89 \pm 0.15 a$ \\
\hline $\mathrm{Ca}\left(\right.$ meq $\left.100 \mathrm{~g}^{-1}\right)$ & $6.74 \pm 1.83 b$ & $13.04 \pm 2.13 \mathrm{a}$ \\
\hline $\mathrm{Mg}\left(\right.$ meq $\left.100 \mathrm{~g}^{-1}\right)$ & $1.49 \pm 0.19 \mathrm{~b}$ & $2.41 \pm 0.29 \mathrm{a}$ \\
\hline $\mathrm{Na}\left(\right.$ meq $\left.100 \mathrm{~g}^{-1}\right)$ & $0.88 \pm 0.06 \mathrm{a}$ & $0.83 \pm 0.04 a$ \\
\hline EA $\left(\right.$ meq $\left.100 \mathrm{~g}^{-1}\right)$ & $2.10 \pm 0.50 \mathrm{a}$ & $0.32 \pm 0.06 \mathrm{~b}$ \\
\hline CEC (meq $100 \mathrm{~g}^{-1}$ ) & $14.91 \pm 1.27 \mathrm{a}$ & $17.60 \pm 1.53 \mathrm{a}$ \\
\hline Sand (\%) & $38.96 \pm 2.80 \mathrm{a}$ & $46.91 \pm 3.58 \mathrm{a}$ \\
\hline Clay (\%) & $35.19 \pm 1.98 \mathrm{a}$ & $24.97 \pm 1.92 b$ \\
\hline Silt (\%) & $25.84 \pm 1.94 \mathrm{a}$ & $28.12 \pm 2.63 \mathrm{a}$ \\
\hline $\mathrm{BD}\left(\mathrm{g} \mathrm{cm}^{-3}\right)$ & $1.05 \pm 0.06 \mathrm{a}$ & $1.02 \pm 0.03 \mathrm{a}$ \\
\hline
\end{tabular}

Mean: 15 replicate \pm Standard error; $\mathrm{pH}$ : potential of hydrogen; OC: organic carbon; N: nitrogen; P: phosphorus; K: potassium; Ca: calcium; Mg: magnesium; Na: sodium; EA: exchangeable acidity; CEC: cation exchange capacity; BD: bulk density Averages followed by equal letters in the row do not differ from each other at $5 \%$ probability.

Lammel et al. (2015) suggested: the high concentration of OC in coffee plantations under organic management is a consequence of the greater addition of organic materials, especially coffee husks. Nitrogen content 
was slightly higher in traditional coffee plantations (Table 2), possibly to the presence of leguminous species biologically fix atmospheric nitrogen (Munroe \& Isaac, 2014).

The concentrations of $\mathrm{K}, \mathrm{Ca}$ and $\mathrm{Mg}$ were significantly higher in traditional coffee plantations (Table 2), possibly attributed to the contribution of organic fertilizer. It was demonstrated by Fernandes et al. (2013), who affirm that depending on the dose of the organic fertilizer, it is produced increases in CEC and in the levels of $\mathrm{Ca}, \mathrm{P}, \mathrm{B}$ and $\mathrm{K}$ in coffee plantations. The exchangeable acidity was higher in intensive coffee plantations (Table 2), attributed to the loss of exchangeable bases (K, Ca, Mg), which occurs through erosion and leaching processes, as well as soil acidification (Effegen et al., 2008).

The principal component analysis explained a $57.8 \%$ variability of edaphic properties data with the first two axes (Figure 2). The axis 1 evidenced that the highest contents of Mg, sand, OC, $\mathrm{pH}, \mathrm{CEC}$ and $\mathrm{K}$ were linked to the plots of traditional coffee plantations (Figure 2). On the other hand, the axis 2 indicated that the content of silt and the bulk density were associated with traditional coffee plantations, while the exchangeable acidity was related with intensive coffee plantations (Figure 2).
The separation of the coffee production systems according to soil properties was significant (p-value: 0.002 ) according to the Monte Carlo test (Figure 2). In this sense, we considered that soil conditions were optimal for macrofauna under traditional coffee plantations due mainly to organic management and the inclusion of shade trees, which produced a more heterogeneous environment with greater soil chemical fertility and a greater food supply for soil macrofauna groups (Kamau et al., 2017; Santos et al., 2018). However, this was only verified for some soil macrofauna groups (Blattodea, Diplopoda and Oligochaeta) (Table 1). Therefore, the distribution of the other groups of soil macrofauna can be attributed to environmental variables such as temperature and soil moisture, which has been widely discussed by various authors as Lavelle et al. (2006) and Santos et al. (2008), or even to soil texture, considered an inherent soil property (Grimaldi et al., 2014).

The co-inertia analysis showed significant covariance (RV: 0.33, p-value: 0.002 , Monte Carlo test) between soil macrofauna and edaphic properties (Figure 3 ). These results coincide with previous studies describing the different relationships between soil macrofauna groups and soil properties (Lima et al., 2010; Vasconcellos et al., 2013; Oliveira et al., 2018).

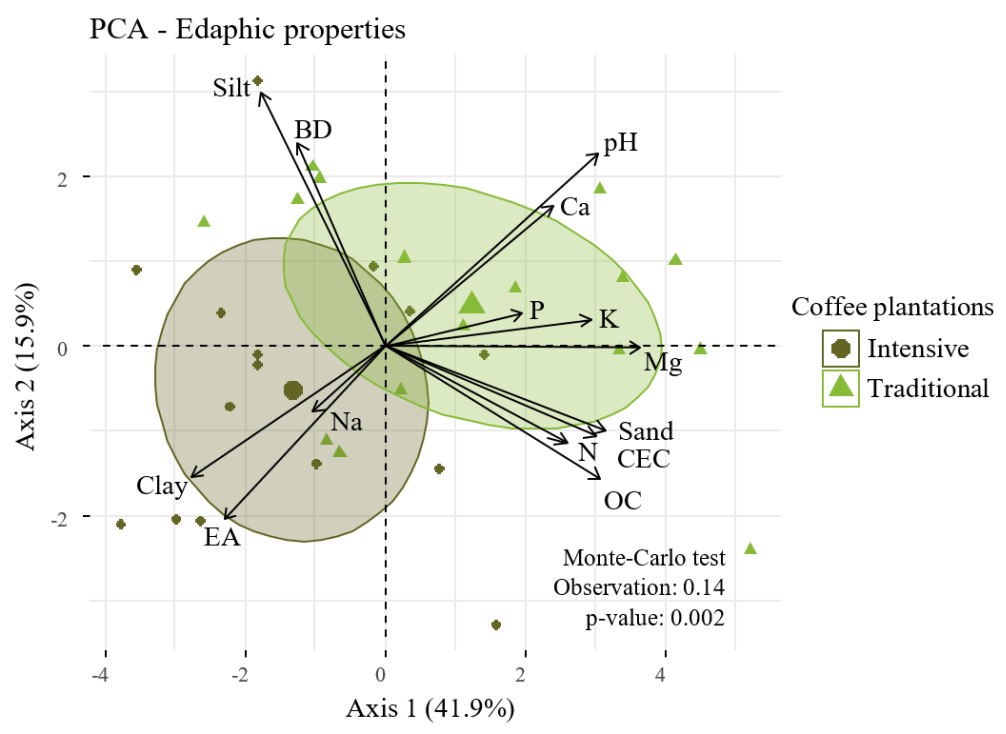

Figure 2. Projection in the F1/F2 factorial plane from a principal component analysis of the edaphic properties and from sampling points grouped according to the coffee production system. $\mathrm{pH}$ : potential of hydrogen; OC: organic carbon; N: nitrogen; P: phosphorus; K: potassium; Ca: calcium; Mg: magnesium; Na: sodium; EA: exchangeable acidity; CEC: cation exchange capacity; BD: bulk density. 
In parallel, the heatmap identified some significant relationships (Figure 4) that help explain the distribution of soil macrofauna abundance under coffee plantations. For example, the Blattodea, Collembola, Diplopoda, Hemiptera and Isopoda groups showed significant correlations with some parameters such as $\mathrm{pH}, \mathrm{CO}, \mathrm{N}, \mathrm{Ca}, \mathrm{Mg}$ and CEC. Like soil macrofauna, soil chemical properties mentioned above were also characteristic of traditional coffee plantations, and to a lesser extent of intensive coffee plantations (Tables 1,2). These findings provide good evidence that changes in soil chemistry could potentially affect the occurrence of soil macrofauna and foster favourable environments for their increased ecological functions (Kamau et al., 2017; Karungi et al., 2018; Santos et al., 2018).

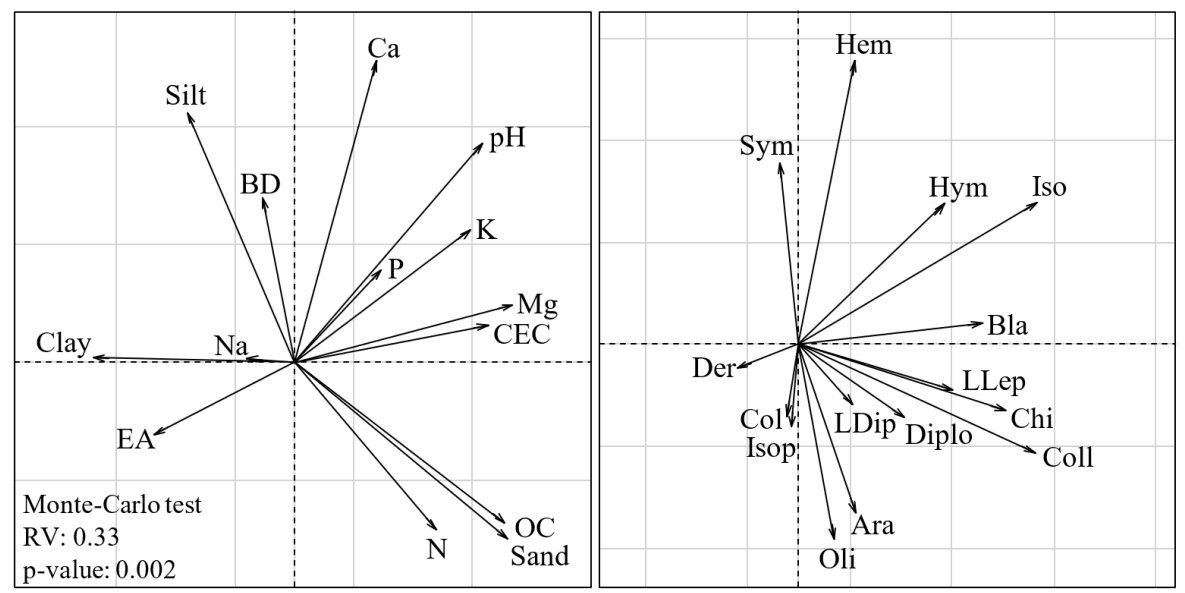

Figure 3. Projection in the F1/F2 factorial plane from a co-inertia analysis of edaphic properties (left) and soil macrofauna (right) in coffee production systems in southern Colombia. $\mathrm{pH}$ : potential of hydrogen; OC: organic carbon; N: nitrogen; P: phosphorus; K: potassium; Ca: calcium; Mg: magnesium; Na: sodium; EA: exchangeable acidity; CEC: cation exchange capacity; BD: bulk density. Ara: Araneae; Bla: Blattodea: Chi: Chilopoda; Coll: Collembola; Col: Coleoptera; Der: Dermaptera; Diplo: Diplopoda; Oli: Oligochaeta; Hem: Hemiptera; Hym: Hymenoptera; Iso: Isopoda; Isop: Isoptera; LDip: Diptera larvae; LLep: Lepidoptera larvae; Sym: Symphyla

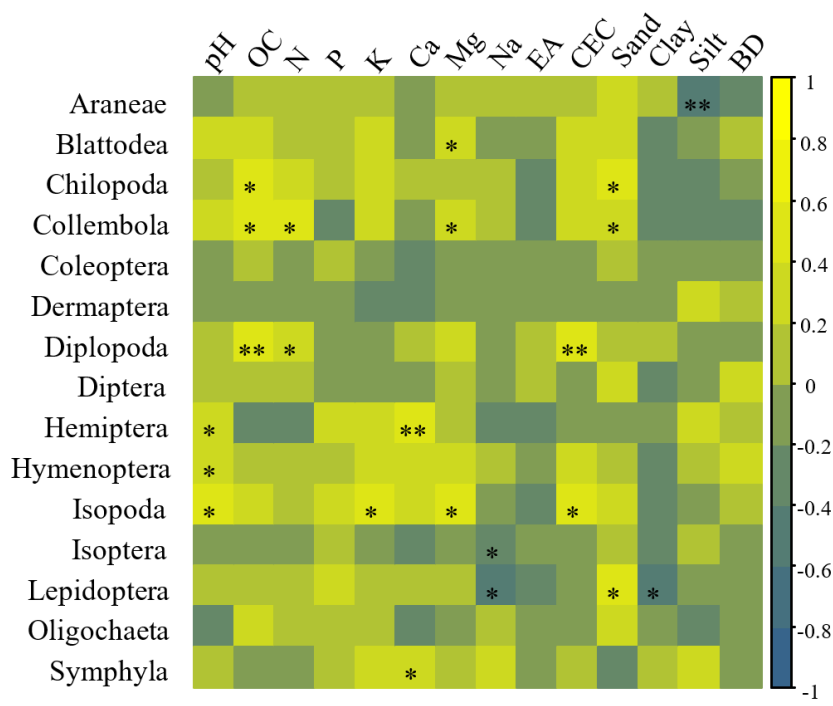

Figure 4. Heatmap of Pearson correlation coefficients between soil macrofauna and edaphic properties. Colors represent the direction and strength of the correlation, ${ }^{*}$ and ${ }^{* *}$ significant correlations at 5 and $1 \%$ probability, respectively. $\mathrm{pH}$ : potential of hydrogen; OC: organic carbon; N: nitrogen; P: phosphorus; K: potassium; Ca: calcium; Mg: magnesium; Na: sodium; EA: exchangeable acidity; CEC: cation exchange capacity; BD: bulk density. 


\section{CONCLUSIONS}

The use of shade trees and the organic management in coffee plantations provided higher soil chemical fertility, resulting in a higher average abundance of soil macrofauna and a highest proportion Blattodea, Diplopoda and Oligochaeta.

Soil macrofauna was correlated with edaphic properties, which indicates that changes in soil chemistry under coffee plantations probably could affect the occurrence of soil macrofauna.

\section{SUBMISSION STATUS}

Received: 11 july 2018

Accepted: 24 nov., 2018

\section{CORRESPONDENCE TO}

\section{Leonardo Rodríguez Suárez}

Universidad de la Amazonia, Calle 17

Diagonal 17 con Carrera 3F, Barrio Porvenir, 180001-180009, Florencia, Caquetá, Colombia e-mail: 1.rodriguezsuarez@outlook.com

\section{REFERENCES}

Aquino AM, Melovirgínio E Fo, Ricci MSF, Casanoves F. População de minhocas em sistemas agroflorestais com café convencional e orgânico. Ciência e Agrotecnologia 2008; 32(4): 1184-1188. http://dx.doi.org/10.1590/S141370542008000400022

Arcila JP, Farfán FV, Moreno AB, Salazar LG, Hincapié EG. Sistemas de producción de café en Colombia. Chinchiná: Federación Nacional de Cafeteros de Colombia - Cenicafé; 2007.

Bartz MLC, Brown GG, Pasini A, Fernandes JDO, Curmi P, Dorioz J et al. Earthworm communities in organic and conventional coffee cultivation. Pesquisa Agropecuária Brasileira 2009; 44(8): 928-933. http://dx.doi.org/10.1590/ S0100-204X2009000800019.

Di Rienzo JA, Casanoves F, Balzarini MG, Gonzalez L, Tablada M, Robledo CW. InfoStat versión 2018 [online]. Argentina: Grupo InfoStat; 2018 [cited 2018 Jul 11]. Available from: http://www.infostat.com.ar

Dray S, Chessel D, Thioulouse J. Co-inertia analysis and the linking of ecological data tables. Ecology 2003; 84(11): 3078-3089. http://dx.doi.org/10.1890/03-0178.

Effegen TAM, Passos RR, Souza JSL, Borges EN, Dardengo MCJD, Reis EF. Atributos químicos do solo e produtividade de lavouras de cafeeiro conilon submetidas a diferentes tratos culturais no sul do Estado do Espírito Santo. Bioscience Journal 2008; 24(6): 7-18.

Farfán F. Agroforestería y sistemas agroforestales con café. Manizales: Federación Nacional de Cafeteros de Colombia - Cenicafé; 2014.

Fernandes ALT, Santinato F, Ferreira RT, Santinato R. Adubação orgânica do cafeeiro, com uso do esterco de galinha, em substituição à adubação mineral. Coffee Science 2013; 8(4): 486-499.

García-Pérez JA, Alarcón-Gutiérrez E, Perroni Y, Barois I. Earthworm communities and soil properties in shaded coffee plantations with and without application of glyphosate. Applied Soil Ecology 2014; 83: 230-237. http:// dx.doi.org/10.1016/j.apsoil.2013.09.006.

Grimaldi M, Oszwald J, Dolédec S, Hurtado MP, Miranda IS, Sartre XA et al. Ecosystem services of regulation and support in Amazonian pioneer fronts: searching for landscape drivers. Landscape Ecology 2014; 29(2): 311-328. http://dx.doi.org/10.1007/s10980-013-9981-y.

Guimarães NDF, Fontanetti A, Fujihara RT, Gallo ADS, Souza MDBD, Morinigo KPG et al. Fauna invertebrada epigéica associada a diferentes sistemas de cultivo do cafeeiro. Coffee Science 2016; 11(4): 484-494.

Guimarães NDF, Gallo ADS, Fontanetti A, Meneghin SP, Souza MD, Morinigo KP et al. Biomassa e atividade microbiana do solo em diferentes sistemas de cultivo do cafeeiro. Revista de Ciências Agrárias 2017; 40(1): 34-44.

Guimarães NDF, Gallo ADS, Souza MDBD, Agostinho PR, Gomes MDS, Silva RFD. Influência de sistemas de produção de café orgânico arborizado sobre a diversidade da fauna invertebrada epigéica. Coffee Science 2015; 10(3): 280-288.

Kamau S, Barrios E, Karanja NK, Ayuke FO, Lehmann J. Soil macrofauna abundance under dominant tree species increases along a soil degradation gradient. Soil Biology \& Biochemistry 2017; 112: 35-46. http://dx.doi.org/10.1016/j. soilbio.2017.04.016.

Karungi J, Cherukut S, Ijala AR, Tumuhairwe JB, Bonabana-Wabbi J, Nuppenau EA et al. Elevation and cropping system as drivers of microclimate and abundance of soil macrofauna in coffee farmlands in mountainous ecologies. Applied Soil Ecology 2018; 131: 1-9. http:// dx.doi.org/10.1016/j.apsoil.2018.08.003.

Lammel DR, Azevedo LCB, Paula AM, Armas RD, Baretta D, Cardoso EJBN. Microbiological and faunal soil attributes of coffee cultivation under different management systems in Brazil. Brazilian Journal of Biology $=$ Revista Brasileira de Biologia 2015; 75(4): 894-905. http://dx.doi. org/10.1590/1519-6984.02414. PMid:26628223.

Lavelle P, Decaëns T, Aubert M, Barot S, Blouin M, Bureau F et al. Soil invertebrates and ecosystem services. European 
Journal of Soil Biology 2006; 42(1): S3-S15. http://dx.doi. org/10.1016/j.ejsobi.2006.10.002.

Lima SS, Aquino AM, Leite LFC, Velásquez E, Lavelle P. Relação entre macrofauna edáfica e atributos químicos do solo em diferentes agroecossistemas. Pesquisa Agropecuária Brasileira 2010; 45(3): 322-331. http://dx.doi.org/10.1590/ S0100-204X2010000300013.

Munroe JW, Isaac MEN. 2-fixing trees and the transfer of fixed-N for sustainable agroforestry: a review. Agronomy for Sustainable Development 2014; 34(2): 417-427. http:// dx.doi.org/10.1007/s13593-013-0190-5.

Oliveira PH, Gama-Rodrigues AC, Gama-Rodrigues EF, Sales MV. Litter and soil-related variation in functional group abundances in cacao agroforests using structural equation modeling. Ecological Indicators 2018; 84: 254262. http://dx.doi.org/10.1016/j.ecolind.2017.08.030.

Pompeo PN, Santos MAB, Biasi JP, Siqueira S, Rosa MG, Baretta CRDM et al. Fauna e sua relação com atributos edáficos em Lages, Santa Catarina-Brasil. Scientia Agraria 2016; 17(1): 42-51. http://dx.doi.org/10.5380/ rsa.v17i1.46535.

R Core Team. R: A language and environment for statistical computing [online]. Vienna: R Foundation for Statistical Computing; 2018 [cited 2018 Jul 11]. Available from: https://www.R-project.org/

Rousseau GX, Deheuvels O, Arias IR, Somarriba E. Indicating soil quality in cacao-based agroforestry systems and old-growth forests: the potential of soil macrofauna assemblage. Ecological Indicators 2012; 23: 535-543. http:// dx.doi.org/10.1016/j.ecolind.2012.05.008.
Santos GG, Silveira PM, Marchão RL, Becquer T, Balbino LC. Macrofauna edáfica associada a plantas de cobertura em plantio direto em um Latossolo Vermelho do Cerrado. Pesquisa Agropecuária Brasileira 2008; 43(1): 115-122. http://dx.doi.org/10.1590/S0100-204X2008000100015.

Santos JB, Ramos AC, Azevedo R Jr, Oliveira LCI Fo, Baretta D, Cardoso EJBN. Soil macrofauna in organic and conventional coffe plantations in Brazil. Biota Neotropica 2018; 18(2): 1-13. http://dx.doi.org/10.1590/1676-0611bn-2018-0515.

Sauvadet M, Van den Meersche K, Allinne C, Gay F, Virginio EM Fo, Chauvat $M$ et al. Shade trees have higher impact on soil nutrient availability and food web in organic than conventional coffee agroforestry. The Science of the Total Environment 2019; 633: 1065-1074. PMid:30308878.

Teixeira AFR, da Silva VM, Mendonça ES. Fauna edáfica em sistemas arborizados de café conilon em solo de tabuleiros costeiros. Coffee Science 2014; 9(3): 385-393.

Tscharntke T, Clough Y, Bhagwat SA, Buchori D, Faust H, Hertel D et al. Multifunctional shade-tree management in tropical agroforestry landscapes-a review. Journal of Applied Ecology 2011; 48(3): 619-629. http://dx.doi. org/10.1111/j.1365-2664.2010.01939.x.

Vasconcellos RL, Segat JC, Bonfim JA, Baretta D, Cardoso EJ. Soil macrofauna as an indicator of soil quality in an undisturbed riparian forest and recovering sites of different ages. European Journal of Soil Biology 2013; 58: 105-112. http://dx.doi.org/10.1016/j.ejsobi.2013.07.001.

Zamudio AM, Carrascal ML, Pulido CE, Gallardo JF, Ávila EA, Vargas MA et al. Métodos analíticos del laboratorio de suelos. Bogotá: Instituto Geográfico Agustín Codazzi; 2006. 